\title{
Effects of currents and tides on fine-scale use of marine bird habitats in a Southeast Alaska hotspot
}

\author{
Gary S. Drew ${ }^{1, *}$, John F. Piatt ${ }^{1}$, David F. Hill ${ }^{2}$ \\ ${ }^{1}$ US Geological Survey, Alaska Science Center, 4210 University Drive, Anchorage, Alaska 99508, USA \\ ${ }^{2}$ Oregon State University, 207 Owen Hall, Corvallis, Oregon 97331, USA
}

\begin{abstract}
Areas with high species richness have become focal points in the establishment of marine protected areas, but an understanding of the factors that support this diversity is still incomplete. In coastal areas, tidal currents - modulated by bathymetry and manifested in variable speeds-are a dominant physical feature of the environment. However, difficulties resolving tidally affected currents and depths at fine spatial-temporal scales have limited our ability to understand their influence on the distribution of marine birds. We used a hydrographic model of the water mass in Glacier Bay, Alaska, USA, to link depths and current velocities with the locations of 15 common marine bird species observed during fine-scale boat-based surveys of the bay conducted during June of 4 consecutive years (2000 to 2003). Marine birds that forage on the bottom tended to occupy shallow habitats with slow-moving currents; mid-water foragers used habitats with intermediate depths and current speeds; and surface-foraging species tended to use habitats with fast-moving, deep waters. Within foraging groups there was variability among species in their use of habitats. While species obligated to foraging near bottom were constrained to use similar types of habitat, species in the mid-water foraging group were associated with a wider range of marine habitat characteristics. Species also showed varying levels of site use depending on tide stage. The dramatic variability in bottom topography-especially the presence of numerous sills, islands, headlands and channels - and large tidal ranges in Glacier Bay create a wide range of current-affected, fine-scale foraging habitats that may contribute to the high diversity of marine bird species found there.
\end{abstract}

KEY WORDS: Current velocity $\cdot$ Tides $\cdot$ Bathymetry $\cdot$ Seabirds $\cdot$ Glacier Bay

Resale or republication not permitted without written consent of the publisher

\section{INTRODUCTION}

As resource exploitation and anthropogenic disturbance of marine ecosystems have increased, there has been a commensurate increase in the effort to identify and protect biodiversity (Boersma \& Parrish 1999, Hyrenbach et al. 2000, Yen et al. 2006, Nur et al. 2011). Marine birds represent the most visible component of these systems, yet our understanding of the factors that affect their habitat use and local diversity are limited.

At coarse scales (100 to $1000 \mathrm{~km}$ ), increased numbers and species of marine birds have been associ- ated with large oceanographic features such as fronts and upwellings (Hunt \& Schneider 1987, Hunt et al. 1998, Spear et al. 2001, Piatt et al. 2006, Suryan et al. 2006, Weimerskirch 2007). However, at finer scales, associations between oceanographic features and marine bird distributions have been more difficult to quantify (Schneider \& Piatt 1986, Hunt \& Schneider 1987, Fauchald et al. 2000). This difficulty has been attributed to the imperfect knowledge of predators regarding where and when prey are available (Schneider \& Piatt 1986), the mismatch between ecosystem components (Francis et al. 1998) and the patchy and ephemeral nature of the prey concentra- 
tions (Hunt \& Schneider 1987). One factor that has not been well studied is the role of fine-scale spatial and temporal variability of environmental factors affecting the distribution of marine birds. In part, this has been due to a lack of high-resolution environmental data.

The issue of fine-scale habitat use is of particular importance for understanding the distribution of marine birds in coastal areas, where tidally affected currents and water depths provide high levels of spatial and temporal habitat heterogeneity. Bottom depth directly affects accessibility to prey, especially for obligate bottom-feeding species, while current speed affects prey encounter rates (Sims et al. 2008) and may contribute to the concentration or dispersion of prey aggregations (Alldredge \& Hamner 1980). In Alaska, tide-related changes in depth are not insignificant, as tides routinely range in height between 3 and $5 \mathrm{~m}$, with extremes of up to $13 \mathrm{~m}$. In coastal areas, tidal regimes should provide marine birds with predictable foraging conditions due to diurnal and monthly cycles (Holm \& Burger 2002).

Until recently, the difficulties of acquiring high-resolution $(100 \mathrm{~m})$ data on constantly changing physical factors such as tidal currents have limited our ability to test for associations at these scales. Recent advances in high-resolution hydrographic models make it possible to model fine-scale current speeds and depths over time and, therefore, to directly assess tidal effects on habitat use by different marine species (Etherington et al. 2007, Chenoweth et al. 2011). In addition to current strength and depth, tidal current direction (ebb or flood) may also be important. Black-legged kittiwakes Rissa tridactyla in Prince William Sound were found to concentrate their foraging efforts during ebbing tides (Irons 1998), and, in the Bering Sea, murre Uria spp. foraging has been linked to tidal ebbs (Coyle et al. 1992).

Glacier Bay, a glacially affected fjord in southeast Alaska, is known to have high primary productivity (Etherington et al. 2007), diverse fish communities (Arimitsu et al. 2003) and a diverse assemblage of marine top-predators (Drew et al. 2008). Speciesrichness data from the North Pacific Pelagic Seabird Database (NPPSD) (USGS 2012) indicate that Glacier Bay is a regional marine bird hotspot (Fig. 1). Species that comprise the diverse Glacier Bay marine bird community (Drew et al. 2008) employ a wide variety of foraging strategies and food types. As such, physical factors such as current speed and bottom depth should influence the choice of habitats used by each species in the bay. Our objectives were to investigate the use of habitats created by basic tidal forces, i.e. speed, direction and bottom topography on the distribution of 15 common marine birds in Glacier Bay. From this, we hope to improve our understanding of coastal habitat use and species richness of marine birds in southeast Alaska.

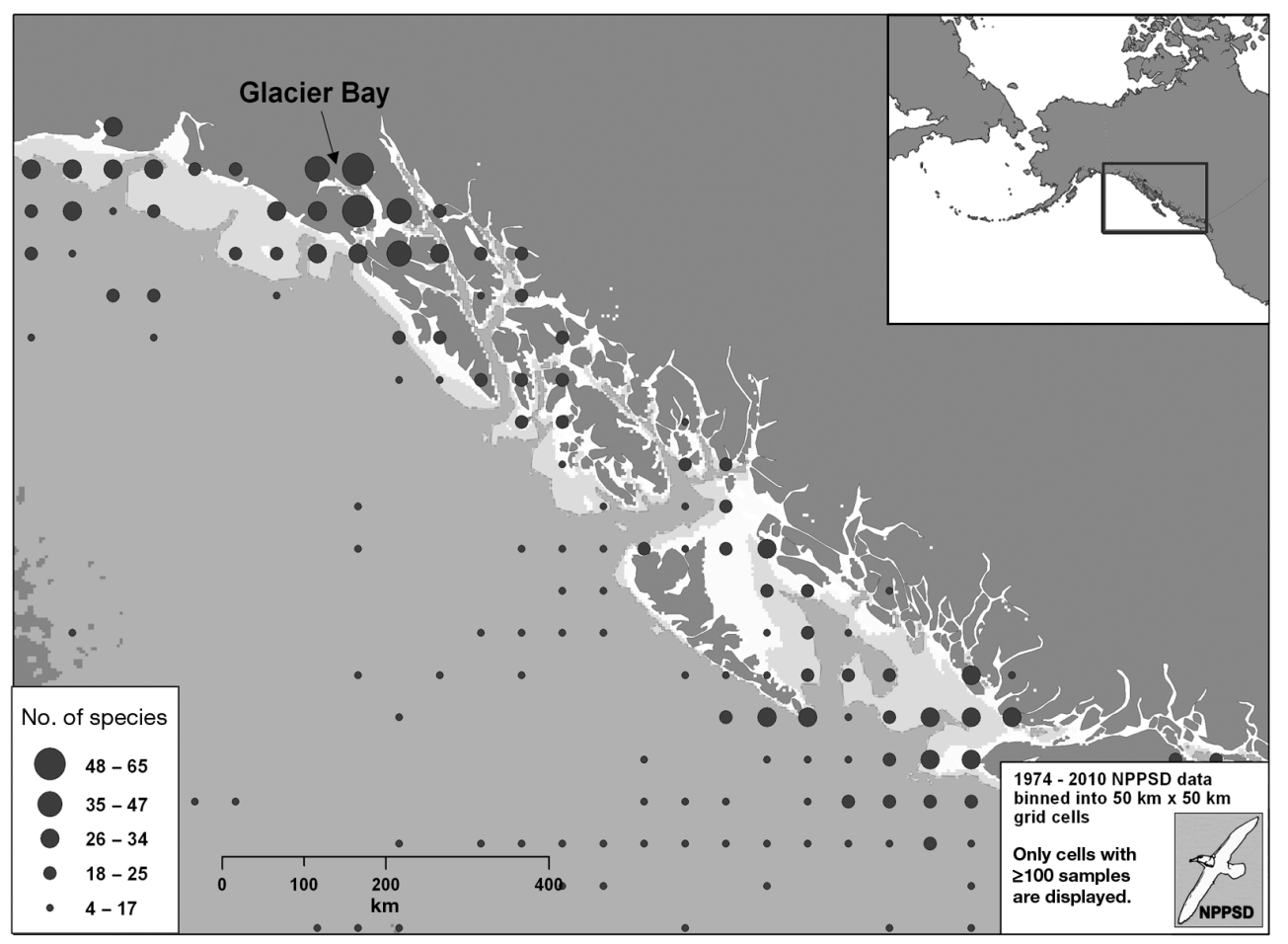

Fig. 1. Species richness across Southeast Alaska, USA, and western British Columbia, Canada. Data were obtained from the North Pacific Seabird Database and binned into $50 \times$ $50 \mathrm{~km}$ cells 


\section{METHODS}

\section{Study area}

Glacier Bay is a $100 \mathrm{~km}$ long Y-shaped glacial fjord in southeast Alaska, with a complex shoreline that includes several constrictions (Fig. 2). The bathymetry of the bay includes numerous sills and basins up to $457 \mathrm{~m}$ deep (Fig. 2). Tides in the bay range from an average of $3.7 \mathrm{~m}$ at Bartlett Cove to $4.2 \mathrm{~m}$ in the upper part of the bay. The hydrographic interactions of this complex marine area result in a wide range of tidal effects including extreme current speeds and complete mixing in shallow narrow sections such as Sitakaday Narrows (Etherington et al. 2007, Hill et al. 2009). Glacier Bay supports large concentrations of zooplankton and forage fish (Abookire et al. 2002, Robards et al. 2003, Arimitsu et al. 2008), as well as abundant benthic invertebrates (Bodkin et al. 2007). In turn, these forage resources support a large number and variety of marine bird species (Robards et al. 2003, Bodkin et al. 2007).

\section{Bird survey design}

We conducted surveys for marine birds and mammals in Glacier Bay, Alaska, during the summers of 2000 to 2003 using a systematic design to sample all areas of the bay. The entire coastline of Glacier Bay was surveyed, and offshore areas were sampled with a series of transects perpendicular to the shore spaced $2.5 \mathrm{~km}$ apart. We used strip-transect protocols established by the US Fish and Wildlife Service (USFWS) for census of marine bird and mammal communities (Gould \& Forsell 1989). All marine birds observed within the $300 \mathrm{~m}$ wide strip-transect were recorded continuously. Because surveys were conducted during the reproductive season when energetic needs peak, we expected that this would also be the period with the strongest correlation between the availability of prey and the distribution of top predators. We included all observations of surfaceforaging birds, due to our inability to distinguish active searching from transiting. For all other species only those on the water were used for analysis. Detailed descriptions of the survey tracks and methodology can be found in Drew et al. (2008).

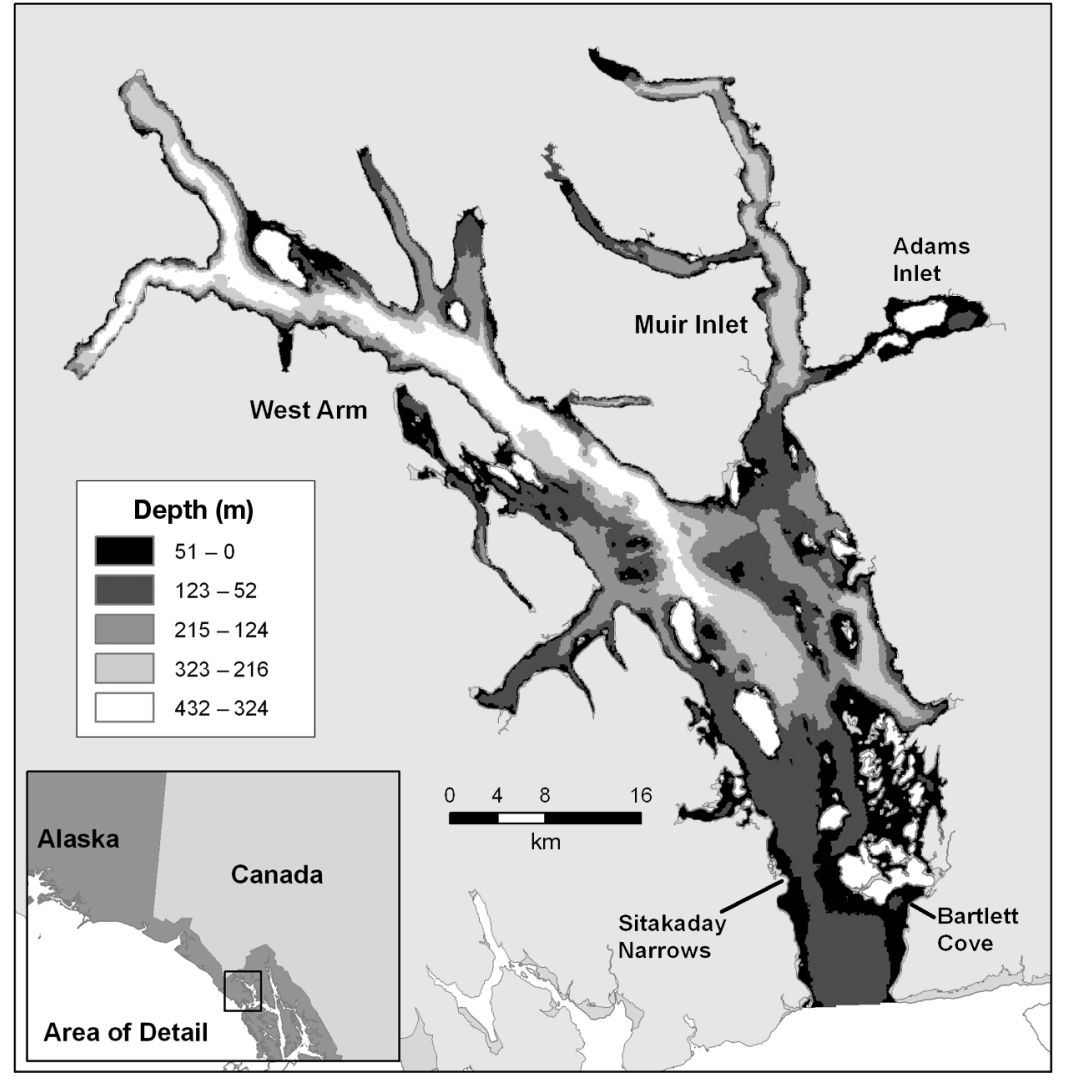

Fig. 2. Glacier Bay study area, associated bathymetry and place names

\section{Current modeling}

To investigate correlations between bird observation locations and tidal conditions, 2 different measures of tidal velocity were computed. The first was the root-mean-square (RMS) value of the velocity. Mean values of tidal velocity are generally very close to zero, when averaged over many tidal cycles; therefore, the RMS value is a much more useful indicator of tidal strength and potential mixing of the water column. The second measure of interest was simply the modeled instantaneous depth-averaged (barotropic) velocity at each bird observation site, at the time of observation.

To obtain both of these measures of tidal velocity, the tidal model ADCIRC (Luettich \& Westerink 1991) was applied to the Glacier Bay region. ADCIRC uses an unstructured finite-element mesh in the horizontal plane and can be run in 3-dimensional or 2-dimensional 
depth-averaged modes. The model can be forced with open boundary tides, freshwater runoff, and surface wind stress and pressure fields. ADCIRC outputs time series of elevation and velocity and (optionally) harmonic analysis results. Previous application of the model to Glacier Bay revealed the rich spatial structure of tidal amplitudes and barotropic velocity circulation patterns (Hill et al. 2009). The computational extent of both that and the present modeling effort included all of Glacier Bay proper, as well as the outlying waters of Icy Strait and Cross Sound. Tidal parameters predicted by computational runs with this mesh were validated by demonstrating excellent agreement with values accepted and distributed by the National Oceanographic and Atmospheric Association (NOAA) (Hill et al. 2009).

For our study, estimates of RMS tidal velocity were derived from simulating $90 \mathrm{~d}$ of tidal motion. The open boundaries were forced with 10 tidal constituents drawn from the ENPAC database (Spargo et al. 2004). After $30 \mathrm{~d}$ of ramp-up, to help suppress initial transients, harmonic analysis was applied to the remaining $60 \mathrm{~d}$ of model output to determine the amplitudes and phases of the primary tidal constituents for both water surface elevation and water velocity. RMS velocities were obtained from these constituents.

To estimate instantaneous tidal velocity, a total of 4 computational runs were conducted, 1 for each summer survey (2000 to 2003). Each model run began with a ramp-up before the first bird observation and lasted until the last bird observation. As with the RMS runs, the model was forced by tides at the 2 open boundaries (Spargo et al. 2004). No meteorological or river forcing was used. Figs. $9 \& 10$ of Hill et al. (2009) demonstrate that the depth-averaged velocity is strongly dominated by tidal forcing, as opposed to the freshwater runoff, justifying this choice. The nodal factors and equilibrium arguments, which are used to set the 'starting time' for each simulation, were obtained from the $\mathrm{T}_{-}$TIDE Matlab package (Pawlowicz 2002).

For each model run, time series of water surface elevation and velocity were computed and recorded in 30 min intervals, at every location reporting a bird observation for that particular year. As a final step, the output data were temporally interpolated to the exact observation times, thereby providing an 'instantaneous' calculation of tidal elevation and velocity at each observation location (latitude, longitude) at the time of observation.

\section{Data analysis}

To examine the differential use of habitats by marine birds in relation to the physical factors that define them, we used the ADCIRC model to identify depth and current values associated with each observation time and location collected during boat surveys. Tidal stage was determined by extracting tidal information using the NOAA Tide/Current Predictor (www.tidesandcurrents.noaa.gov). Although there is some variation in tides across the length of Glacier Bay, we were restricted to the only tide station in Bartlett Cove, which had a range of $3.7 \mathrm{~m}$ (Fig. 2). The extracted data had a resolution of $1 \mathrm{~min}$ and were assigned as either ebb or flood. We used time to match the tidal stage with the ADCIRC output for each bird observation. Due to the variability in group size and the affinity for grouping among some species, we treated all observations, whether of groups or single birds, as a single observation. We classified the 15 species into 3 groups, surface feeders, midwater feeders and bottom feeders, based on their foraging habits within the water column.

Logistic regression was used to test the presence or absence of each species or foraging group for associations, when birds were observed, with 3 variables: (1) instantaneous depth, hereafter referred to as used depth; (2) instantaneous current speed, hereafter referred to as used current; and (3) tidal direction (ebb or flood). Although wind has long been identified as an important factor in coastal upwelling (Smith 1968, Small \& Menzies 1981), previous research on the oceanographic patterns in Glacier Bay suggested that wind was not a major factor influencing the stability of the water column in the bay (Etherington et al. 2007); therefore, we did not include it in our analysis.

While the logistic regressions indicate which of the environmental factors are influencing the use of sites by species, marine habitats are temporally variable. Species may select locations during periods when currents or depths are higher or lower than expected based on the RMS currents or mean sea level (MSL). These patterns of use may provide a form of resource partitioning between species. For example, some species may use habitats with high RMS currents, but only when currents are below the RMS value. The logistic regressions could identify the use of high or low current speeds, but not whether currents or depths were higher or lower than expected based on average values. Use of sites during periods with specific current or depth conditions could provide 
insights regarding results of our logistic regressions. Fortunately, the ADCIRC model provided both instantaneous and RMS current speeds, as well as instantaneous and MSL depths. We used paired $t$-tests to compare used versus RMS current speeds and used versus MSL depths for all species. A significant result in the paired $t$-test would suggest that a species was using areas at current flows different from the RMS values. We used $95 \%$ CI plots of the difference between used and expected currents and depths to identify whether species were using sites under specific conditions. If a species focused their use on an area regardless of instantaneous current and depth factors, we would expect the mean use to be zero.

\section{RESULTS}

There is a general increase in RMS current speeds moving from the head of Glacier Bay to the mouth (Hill et al. 2009). Areas of physiographic con-

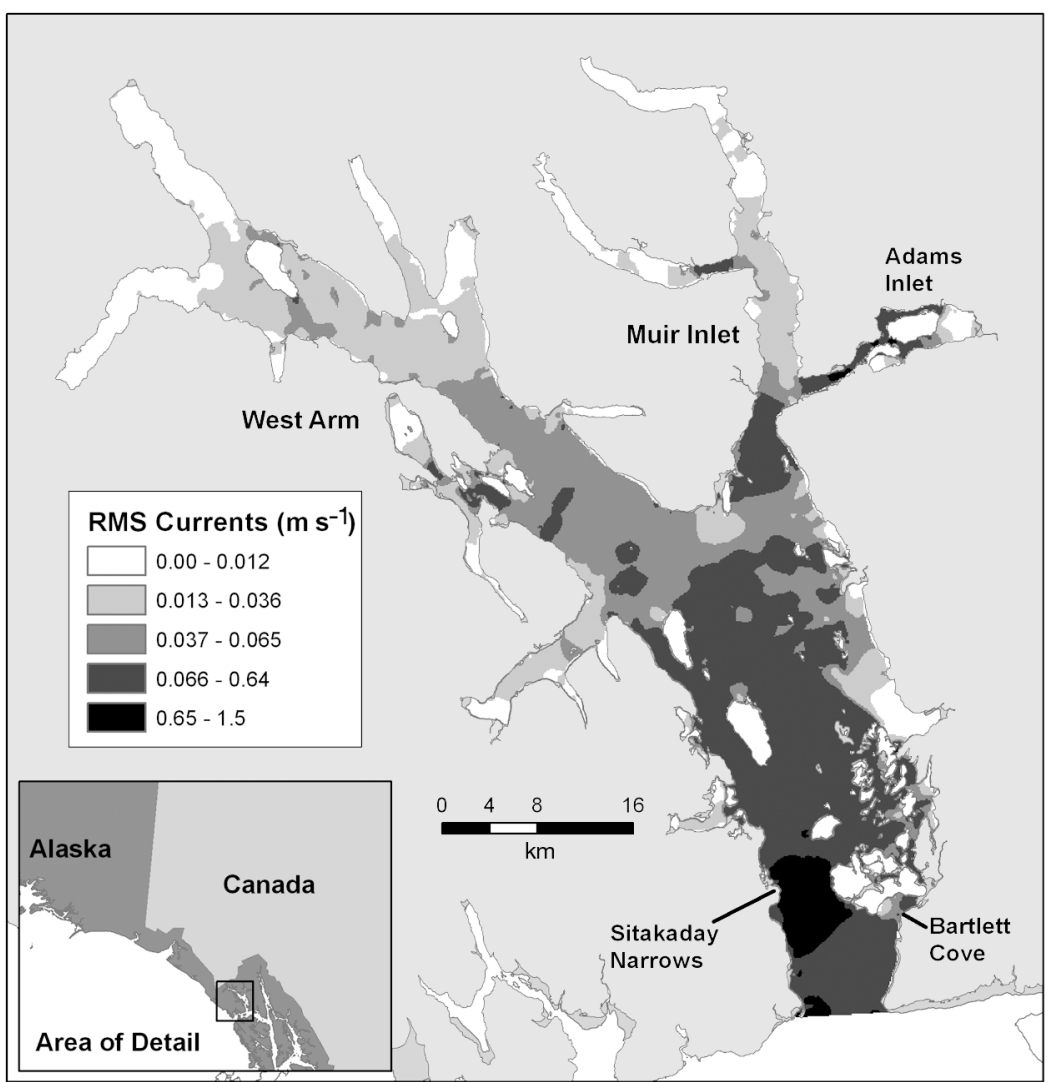

Fig. 3. Tidal currents in Glacier Bay, Alaska. Root-mean-square (RMS) current flow from the ADCIRIC model. Light areas: low currents, dark areas: high currents (see key) striction, such as those found at Sitakaday Narrows and in Adams inlet (Fig. 2) were characterized by particularly high RMS values (Fig. 3). Although there was a correlation between bottom depth and current speed $(\mathrm{n}=12995, \mathrm{p}<$ 0.001 ), depth explained $<1.3 \%$ of the variation in current speeds, so we treated these 2 factors as independent.

\section{Habitat associations of foraging groups}

Logistic regressions conducted on the 3 foraging groups indicated differences in the use of sites by depth and current speed (Table 1). Bottom foragers used shallow habitats (Fig. 4) with slow average current speeds (Fig. 5). Surface foragers used habitats with deeper water (Fig. 4) and the fastest current speeds (Fig. 5). Mid-water foraging birds used habitats that fell between the other 2 groups in terms of both depth and current speed. None of the 3 foraging groups showed any preference for tidal direction (Table 1).

\section{Habitat associations by species}

Depth was a significant factor in the use of sites by the majority of species. Of the 15 species tested, 11 had an association with depth (Table 1; see also for scientific names and codes). Glaucous-winged gulls, black-legged kittiwakes, marbled murrelets and Kittlitz's murrelets used sites with depths greater than the average for other species (Fig. 6). Conversely, mew gulls, common loons, pelagic cormorants, common mergansers, pigeon guillemots, harlequin ducks and white-winged scoters used habitats that were shallower than the average for other species (Fig. 6). In addition to species-specific differences in selected depths, there was considerable variation within all foraging groups. These differences were most pronounced in the mid-water group which contained the species using the shallowest depths (common merganser) and the deepest depths (Kittlitz's murrelet).

Significant associations were identified between current speeds and 10 of the 15 species tested (Table 1). Glaucous-winged gulls, black-legged kittiwakes, 
Table 1. Logistic regressions on 15 species and 3 foraging groups testing for associations with depth, currents and tidal direction. Marine bird survey data were collected in Glacier Bay, Alaska, USA, during the summers of 2000 to 2003 . ns: not significant; ${ }^{*}: p<0.05 i^{* *}: p<0.01 i^{* * *}: p<0.001$

\begin{tabular}{|c|c|c|c|c|c|c|c|}
\hline Species & Code & $\begin{array}{l}\text { Foraging } \\
\text { group }\end{array}$ & $\begin{array}{l}\text { Observations } \\
\text { (n) }\end{array}$ & $\begin{array}{l}\text { Depth } \\
\text { (m) }\end{array}$ & $\begin{array}{l}\text { Current } \\
\left(\mathrm{m} \mathrm{s}^{-1}\right)\end{array}$ & $\begin{array}{l}\text { Ebb- } \\
\text { Flood }\end{array}$ & Direction \\
\hline \multicolumn{8}{|l|}{ Surface foraging group } \\
\hline Glaucous-winged gull Larus glaucescens & GWGU & Surface & 1626 & $*$ & $* * *$ & $* *$ & Ebb \\
\hline Herring gull Larus argentatus & HEGU & Surface & 160 & ns & ns & ns & - \\
\hline Mew gull Larus canus & MEGU & Surface & 673 & $* * *$ & ns & ** & Ebb \\
\hline Black-legged kittiwake Rissa tridactyla & BLKI & Surface & 1590 & $* * *$ & $* * *$ & ** & Flood \\
\hline Arctic tern Sterna paradisaea & ARTE & Surface & 534 & ns & $* * *$ & * & Flood \\
\hline Overall surface foragers & & Surface & 3722 & $* * *$ & $* * *$ & ns & - \\
\hline \multicolumn{8}{|l|}{ Mid-water foraging group } \\
\hline Common loon Gavia immer & COLO & Mid-water & 96 & *** & ns & ns & - \\
\hline Pacific loon Gavia pacifica & PALO & Mid-water & 83 & ns & ns & ns & - \\
\hline Pelagic cormorant Phalacrocorax pelagicus & PECO & Mid-water & 97 & * & * & $*$ & Flood \\
\hline Common merganser Mergus merganser & COME & Mid-water & 299 & $* * *$ & $* * *$ & ns & - \\
\hline Marbled murrelet Brachyramphus marmoratus & MAMU & Mid-water & 3265 & $* * *$ & $* * *$ & ns & - \\
\hline Kittlitz's murrelet Brachyramphus brevirostris & KIMU & Mid-water & 752 & $* * *$ & ns & ns & - \\
\hline Pigeon guillemot Cepphus columba & PIGU & Mid-water & 3136 & $* * *$ & $* * *$ & $*$ & Ebb \\
\hline Overall mid-water foragers & & Mid-water & 7620 & $* * *$ & $* * *$ & ns & - \\
\hline \multicolumn{8}{|l|}{ Bottom foraging group } \\
\hline Harlequin duck Histrionicus histrionicus & HADU & Bottom & 279 & $* * *$ & ** & ns & - \\
\hline White-winged scoter Melanitta fusca & WWSC & Bottom & 246 & $* * *$ & $*$ & ns & - \\
\hline Surf scoter Melanitta perspicillata & SUSC & Bottom & 194 & ns & $* *$ & ns & - \\
\hline Overall bottom foragers & & Bottom & 719 & $* * *$ & $* * *$ & ns & - \\
\hline
\end{tabular}

Arctic terns, common mergansers, pigeon guillemots and marbled murrelets were associated with faster currents (Fig. 7). Pelagic cormorants, harlequin ducks, white-winged scoters and surf scoters were associated with slower currents (Fig. 7). There was considerable variation in used current speeds among species in the surface foraging and mid-water foraging groups. However, bottom foraging species were more uniform, with all being associated with slower than expected current speeds.

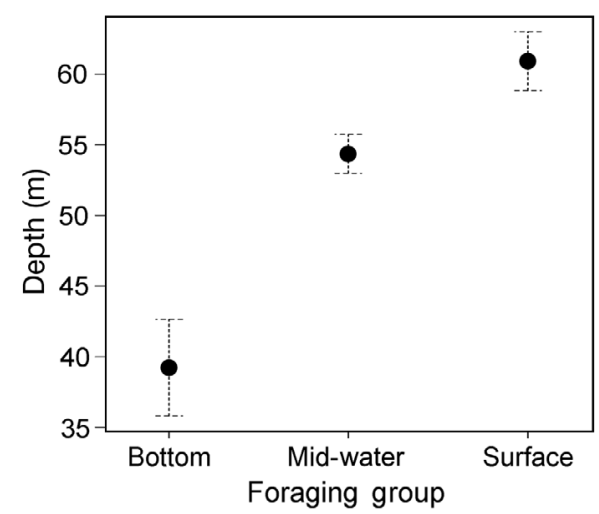

Fig. 4. Depths at marine bird observation sites within Glacier Bay (2000 to 2003) grouped into 3 foraging classes: bottom, $(\mathrm{n}=719)$, mid-water $(\mathrm{n}=7620)$ and surface $(\mathrm{n}=3722)$. Means $\pm 95 \%$ CI
Tidal direction was significantly associated with the use of areas by glaucous-winged gulls, mew gulls, black-legged kittiwakes, Arctic terns, pelagic cormorants and pigeon guillemots (Table 1). Tidal direction was identified as significant for 4 of the 5 surface foragers and 2 of the 7 mid-water foragers. None of the 3 bottom foragers displayed any association with tidal direction. Herring gulls Larus argentatus were the only surface foraging species that was not associated with tidal direction, but were also

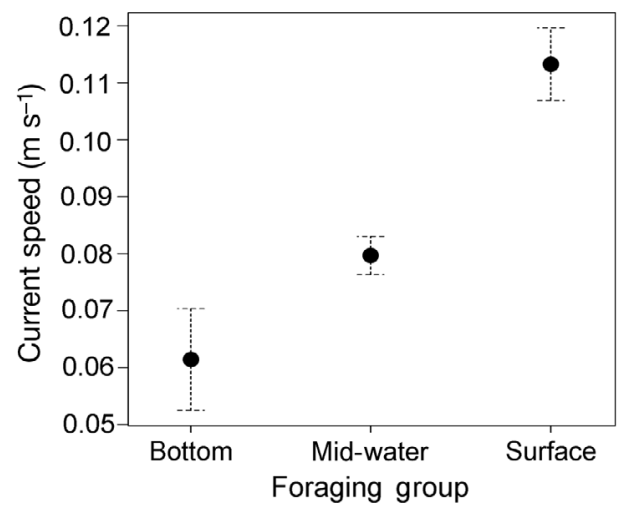

Fig. 5. Current speed at marine bird observation sites within Glacier Bay (2000 to 2003) grouped into 3 foraging classes: bottom $(\mathrm{n}=719)$, mid-water $(\mathrm{n}=7620)$ and surface $(\mathrm{n}=$ 3722). Means $\pm 95 \% \mathrm{Cl}$ 


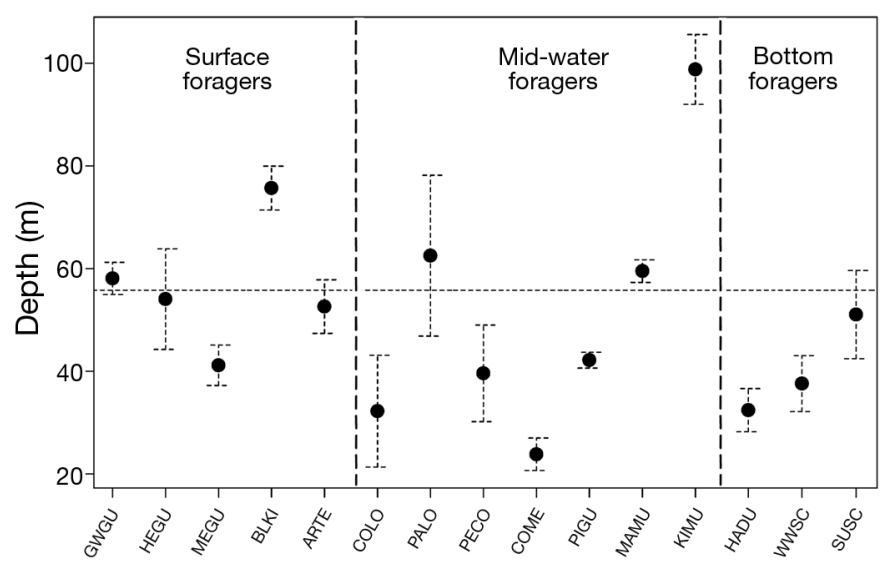

Fig. 6. Depths at observation sites for 15 species in Glacier Bay. Means $\pm 95 \%$ CI. Dashed horizontal line: overall mean depth for all observed birds. Vertical dashed lines separate foraging groups. Species codes see Table 1

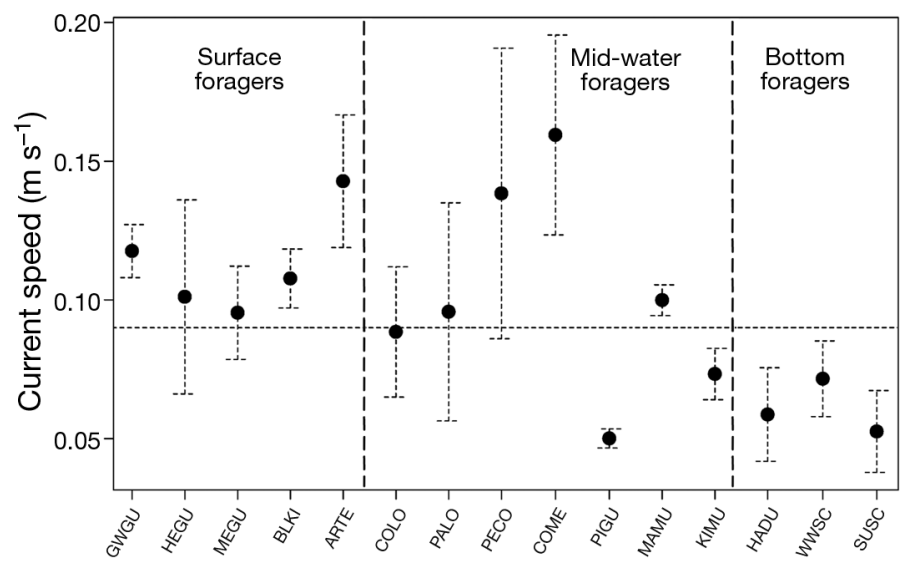

Fig. 7. Current speeds at observation sites for 15 species in Glacier Bay. Means $\pm 95 \%$ CI. Dashed horizontal line: overall mean depth for all observed birds. Vertical dashed lines separate foraging groups. Species codes see Table 1

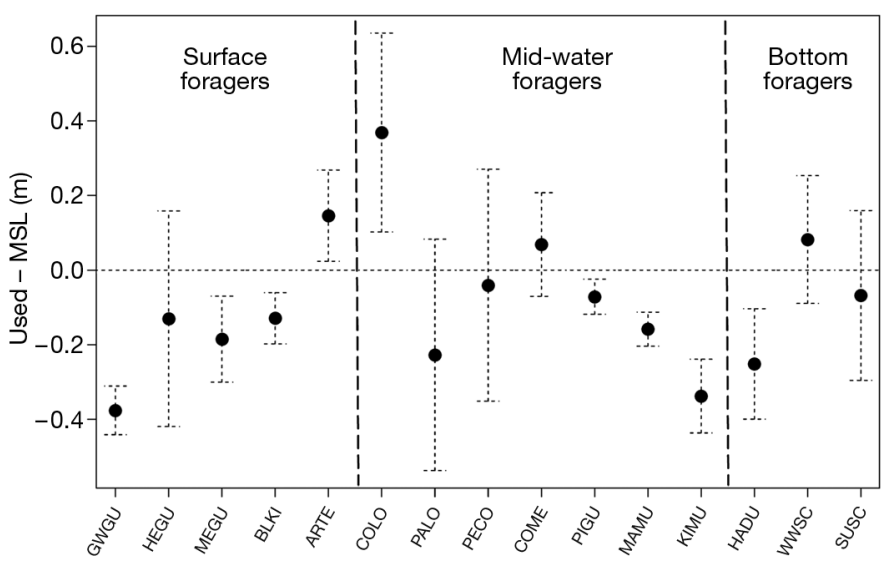

Fig. 8. Deviations from mean sea level (MSL) at observation sites for 15 species in Glacier Bay. Means $\pm 95 \%$ CI. Dashed horizontal line: no difference between used depths and MSL. Vertical dashed lines separate foraging groups. Species codes are given in Table 1 the least common species (Table 1). Among the midwater foraging species that exhibited a preference for tidal direction, 4 most commonly used floods and 3 most commonly used ebbs. Within groups there was no consistency in the choice of tidal direction.

Paired comparisons between instantaneous depths and MSL indicated that 9 of the 15 species used sites when depths were significantly different than the average (Table 2). Plots of used versus MSL depths indicated that Arctic terns and common loons used sites when depths were greater than expected (Fig. 8). Conversely, glaucous-winged gulls, mew gulls, black-legged kittiwakes, pigeon guillemots, marbled murrelets, Kittlitz's murrelets and harlequin ducks used sites when depths were less than expected for used locations (Fig. 8).

Paired comparisons between instantaneous currents and RMS (average) currents for these same locations indicated that 7 of the 15 species used sites when currents were significantly different than the RMS currents. Glaucous-winged gulls, black-legged kittiwakes, Pacific loons Gavia pacifica, pigeon guillemots, marbled murrelets, Kittlitz's murrelets and white-winged scoters used sites based on relative current speed (Table 2). Plots of used versus RMS currents indicated that all of these 7 species tended to use habitats when current speeds at the time of observation were lower than the RMS average at that location (Fig. 9). No species tended to use habitats when instantaneous speeds were greater than the RMS speeds.

Table 2. Paired $t$-tests comparing used currents and depths versus the root-mean-square currents and mean sea level values for each observed species location. Foraging group: $\mathrm{S}=$ surface, $\mathrm{M}=$ mid-water, $\mathrm{B}=$ bottom. ${ }^{*}: \mathrm{p}<0.05{ }^{* *}: \mathrm{p}<$ $0.01 i^{* * *}: \mathrm{p}<0.001$. Species codes see Table 1

\begin{tabular}{|lcccc|}
\hline \multirow{2}{*}{$\begin{array}{l}\text { Species } \\
\text { code }\end{array}$} & $\begin{array}{c}\text { Foraging } \\
\text { group }\end{array}$ & df & \multicolumn{2}{c|}{ t-test- } \\
\cline { 5 - 6 } GWGU & $\mathrm{S}$ & 1507 & $-9.075^{* * *}$ & $-11.310^{* * *}$ \\
HEGU & $\mathrm{S}$ & 116 & -1.131 & -0.893 \\
MEGU & $\mathrm{S}$ & 542 & 1.023 & $-3.155^{* *}$ \\
BLKI & $\mathrm{S}$ & 1475 & $-4.231^{* * *}$ & $-3.685^{* * *}$ \\
ARTE & $\mathrm{S}$ & 501 & 0.677 & $2.343^{*}$ \\
COLO & $\mathrm{M}$ & 85 & -1.381 & $2.749^{* *}$ \\
PALO & $\mathrm{M}$ & 72 & $-2.000^{*}$ & -1.460 \\
PECO & $\mathrm{M}$ & 85 & -0.544 & -0.258 \\
COME & $\mathrm{M}$ & 262 & 0.733 & 0.972 \\
PIGU & $\mathrm{M}$ & 2803 & $-6.898^{* * *}$ & $-2.970^{* *}$ \\
MAMU & $\mathrm{M}$ & 3085 & $-15.001^{* * *}$ & $-6.788^{* * *}$ \\
KIMU & $\mathrm{M}$ & 717 & $-5.653^{* * *}$ & $-6.709^{* * *}$ \\
HADU & $\mathrm{B}$ & 221 & -0.267 & $-3.345^{* * *}$ \\
WWSC & $\mathrm{B}$ & 220 & $-3.446^{* * *}$ & 0.944 \\
SUSC & $\mathrm{B}$ & 163 & -1.968 & -0.591 \\
\hline
\end{tabular}




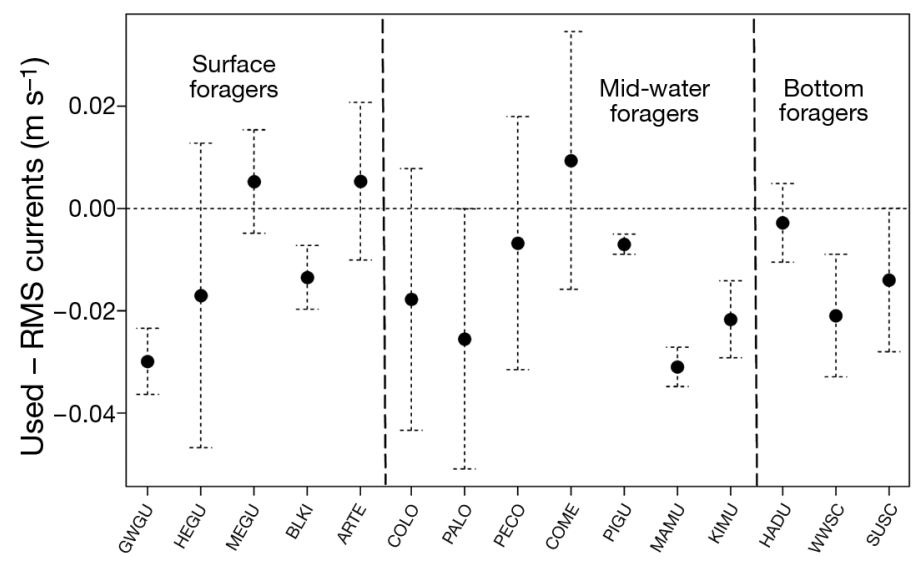

Fig. 9. Deviations from the root-mean-square (RMS) current speeds at observation sites for 15 species in Glacier Bay. Mean $\pm 95 \%$ CI. Dashed horizontal line represents no difference between used current speeds and RMS values. Vertical dashed lines separate foraging groups. Species codes see Table 1

\section{DISCUSSION}

\section{Habitat associations of bottom foraging species}

The use of shallow areas by bottom foragers was both expected and understandable given their foraging constraints. These species must be able to reach bottom and forage efficiently in the substrate (Wilson \& Wilson 1988, Vermeer et al. 1993, Lewis et al. 2008). Bottom foraging species usually feed on sessile prey and only infrequently benefit from concentrations of free-swimming prey in the water column. Access to prey by bottom foragers may be inhibited by high currents due to increased foraging effort (Lovvorn \& Gillingham 1996, Heath \& Gilchrist 2010). Accordingly, bottom foraging species were observed using the lowest absolute and relative current speeds. Our findings are consistent with observations of diving ducks off the coast of British Columbia (Holm \& Burger 2002). Tidal direction was not found to be significant for any bottom foragers.

The use of relatively shallow depths by 2 of the 3 bottom foraging species was expected due to their requirement for access to benthic substrate. Similarly, all 3 bottom foraging species used sites with lower current speeds (but note that pigeon guillemots, from the mid-water foraging group, selected the slowest currents). For species foraging in benthic substrate, costs should increase both with increasing depths and current speed. The prey items for bottom foragers are largely filter-feeding sessile organisms that rely on actively moving water for their food supply (Strathmann 1985). Paradoxically, bottom forag- ing birds forage most efficiently where currents are low, due to energetic costs, but many of their prey may be most common in areas with moderately high currents (Wells 1957, Mileikovsky 1971). Harlequin ducks appear to be particularly sensitive to depth as they used shallow habitats and tended to use them when tides were below MSL. Although bottom foraging species generally favored lower current speeds, white-winged scoters were particularly sensitive to current speeds, using sites when currents were lower than the RMS current. This suggests that whitewinged scoters may be adjusting their forging times to minimize their exposure to the higher currents and presumably higher foraging costs.

\section{Habitat associations of mid-water foraging species}

The disproportionate use of intermediate depths by mid-water foragers may reflect the use of these habitats by their primary prey, schooling fish, while limiting the water column to depths within the dive range of these birds (Coyle et al. 1992, Maniscalco et al. 1998). In general, mid-water foragers were associated with moderate current speeds. Despite the potential benefits of prey being driven closer to the surface with tidal mixing (Begg \& Reid 1997) and increased encounter rates (Sims et al. 2008), high current speeds can also increase the energetic costs of swimming (Lovvorn et al. 2001), and fish schools may be disrupted by high current speeds (Pitcher 1973). Previous research had found associations between mid-water foraging birds during both ebbs (Coyle et al. 1992, Irons 1998, Thompson \& Price 2006) and floods (Zamon 2001); however, this is the first study where a range of species was simultaneously tested. The wide variation in habitat use by mid-water foraging species suggests that this group employs the most diverse set of foraging strategies. In turn, this makes it more difficult to make general conclusions about habitat quality based on physical forces.

Pigeon guillemots used shallow habitats with the slowest currents. While we binned them with the mid-water foragers, and they often feed on pelagic schooling fish, they also are known to forage extensively on epi-benthic fishes (Duffy et al. 1987, Vermeer et al. 1993, Litzow et al. 2004). Indeed, their choice of habitat factors more closely resembled that of the diving ducks rather than other mid-water foraging birds and suggests they employ more of a benthic-feeding strategy in Glacier Bay. The disproportionate use of habitats when tides are below 
MSL depths and currents are below RMS speeds supported our speculation that pigeon guillemots are searching more intensively along the bottom and thus benefit from slower currents and greater access afforded by decreased depths. Alternatively, pelagic cormorants, another species that has been known to forage on epi-benthic fish (Ainley et al. 1981), tended to use high-current habitats. Clearly, these 2 species were using very different strategies despite having similar food habits (Drent 1965, Robertson 1974, Kotzerka et al. 2011). A possible explanation for this difference may be related to different body forms. Research has shown that the longer neck of pelagic cormorants provides them with an energetic advantage over alcids at faster current speeds, but a disadvantage at lower speeds (Lovvorn et al. 2001). Tidal direction was a significant factor for both of these species, but differed in direction, with pelagic cormorants using floods more than expected and pigeon guillemots using ebbs more than expected. It is notable that common mergansers, a mid-water forager similar in size to pelagic cormorants, also used habitats with similar depths and current speeds, suggesting that these species may share similar foraging strategies.

The mid-water foraging group in Glacier Bay contained 2 groups of closely related species, murrelets Brachyramphus spp. and loons Gavia spp. This allowed us to compare habitat use for each of these congeneric pairs. Competition theory suggests that we should expect resource partitioning along important physical gradients. If currents and depths were important in this partitioning we should be able to detect differences in the use of these features. The 2 loon species used similar current speeds and neither showed a preference for tidal direction, but common loons tended to use shallower habitats than Pacific loons. The loons also showed differences in relative habitat use, with common loons using sites when depths were greater than MSL while Pacific loons used habitats when current speeds were less than RMS.

The murrelets also displayed differences in habitat use. Kittlitz's murrelets used deep habitats, but did not show any preference for current speed. Conversely marbled murrelets used faster than expected currents and shallower than expected habitats. This is consistent with frequent observations of marbled murrelets in shallow channels between islands where tide rips are commonly observed (Day et al. 2003). It has been proposed that the larger eye of the Kittlitz's murrelet allows them to forage under low-light conditions (Day et al. 2003). This hypothesis has been tested in relation to highly turbid glacially affected waters (Day et al. 2003); however, we lacked the data necessary to assess the light attenuation in areas where Kittlitz's murrelets were foraging. The ability to forage at relatively greater depths could also explain the use of Kittlitz's murrelet of habitats with lower current speeds. Both murrelet species were associated with sites where depths and current speeds were less than expected, and this pattern was true of all of the small alcids in our study.

\section{Habitat associations of surface foraging species}

Glaucous-winged gulls and black-legged kittiwakes used deeper habitats, whereas mew gulls and Arctic terns tended to disproportionately use shallower habitats. Glaucous-winged gulls, blacklegged kittiwakes and Arctic terns all used habitats with higher than expected current speeds. This was predictable because previous studies have shown an association between elevated current speeds and concentrations of nekton closer to the surface, thereby making them available to surface foragers (Brown \& Gaskin 1988, Hunt et al. 1990, Coyle et al. 1992). We speculate that Arctic terns were taking advantage of foraging opportunities associated with fast currents in Adams Inlet (Fig. 2), which has a very narrow entrance. Of the 5 surface foraging species, 4 were significantly associated with a tidal direction, 2 with ebbs and 2 with floods. This range of associations may be related to differences in foraging strategies. Despite their association with shallow depths, mew gulls used sites when depths were shallower than MSL. This suggests that mew gulls, which commonly forage along the shoreline, are temporally adjusting their habitat use to gain a foraging advantage.

Although black-legged kittiwakes in Prince William Sound, Alaska, have previously been found to forage primarily during ebb tides (Irons 1998), we found black-legged kittiwakes in Glacier Bay to use flood tides more than expected. These results suggest that, at least for black-legged kittiwakes, tidal direction does not impart any general advantage. Interactions between flow direction and other physical factors, including currents and bathymetry, may not be easily generalized. An ebb tide may produce conditions that increase foraging efficiency, e.g. concentration of prey, but the shape of submarine features, strength of current, depth and prey type appear to be more critical than tidal direction.

The disproportionate use of flood tides by Arctic terns may be related to their use of spatially 
restricted areas such as Adam's Inlet where they rely on the tidal floods to bring prey into the inlet or closer to the surface. Because Adam's Inlet also contains an Arctic tern colony site, we cannot discount the influence of proximity to nesting area; however, data available on their foraging range suggest that this should not be a restriction (Pearson 1968, Hatch 2002).

\section{Implications for species richness}

In this paper, we examined the influence of tidally driven currents on the fine-scale habitat use of marine birds in Glacier Bay, Alaska. Our study was unique because we were able to link bird observations to instantaneous environmental factors, including depths and currents at fine spatial-temporal scales. Our results indicate that foraging groups displayed clear differences in habitat use based on current, water depth and tidal direction. Within these groups we also found considerable between-species variation in habitat use, suggesting varying levels of resource partitioning. Owing to dramatic variability in bottom topography-especially the presence of numerous sills, islands, headlands and channelsand large tidal ranges, we suspect that Glacier Bay offers a greater-than-average range of fine-scale foraging habitats. This temporally sensitive habitat diversity may explain the high marine bird diversity in the bay. Although this work was conducted in a topographically complex fjord ecosystem, the concepts of resource partitioning based on tidally driven depth and current associations should be applicable to other coastal areas. As fine- or meso-scale current modeling becomes more available in other areas, it would be instructive to examine the role of current speed and tides on the spatial-temporal availability of habitats and its role in determining the local diversity of marine birds.

Acknowledgements. We thank the US National Park Service and the US Geological Survey (USGS) for providing the funding for this research. In addition to funding, park personnel provided invaluable logistical support. Marine surveys were conducted by employees of the USGS, US Fish and Wildlife Service and the National Park Service. Special thanks to Captains Jim de La Bruere of the USGS vessel RV 'Alaskan Gyre' and Greg Snedgen of the USGS vessel RV 'David Grey' for their capable assistance on surveys. We thank K. Oakley and R. Taylor for comments on the manuscript. Any mention of trade names is for descriptive purposes only and does not reflect endorsement by the federal government.

\section{LITERATURE CITED}

Abookire AA, Piatt JF, Speckman S (2002) A near-surface, daytime occurrence of two mesopelagic fish species (Stenobrachius leucopsarus and Leuroglossus schmidti) in a glacial fjord. Fish Bull 100:376-380

Ainley DG, Anderson DW, Kelly PR (1981) Feeding ecology of marine cormorants in southwestern North America. Condor 83:120-131

> Alldredge AL, Hamner WM (1980) Recurring aggregation of zooplankton by a tidal current. Estuar Coast Mar Sci 10: 31-33

Arimitsu ML, Litzow MA, Piatt JF, Robards MD, Abookire AA, Drew GS (2003) Inventory of marine and estuarine fishes in southeast and central Alaska national parks. Final Rep. for Glacier Bay National Park, US Geological Survey, Anchorage, AK

Begg GS, Reid JB (1997) Spatial variation in seabird density at a shallow sea tidal mixing front in the Irish Sea. J Mar Sci 54:552-565

Bodkin JL, Ballachey BE, Esslinger GG, Kloecker KA, Monson DH, Coletti HA (2007) Perspectives on an invading predator-Sea otters in Glacier Bay. In: Piatt JF, Gende SM (eds) Proc 4th Glacier Bay Sci Symp. US Geol Surv Sci Invest Rep 2007 5047:133-136

Boersma PD, Parrish JK (1999) Limiting abuse: marine protected areas, a limited solution. Ecol Econ 31:287-304

Brown RGB, Gaskin DE (1988) The pelagic ecology of grey and red-necked phalaropes Phalaropus fulicarius and $P$. lobatus in the Bay of Fundy, eastern Canada. Ibis 130: 234-250

Chenoweth EM, Gabriele CM, Hill D (2011) Tidal influences on humpback whale habitat selection near headlands. Mar Ecol Prog Ser 423:279-289

> Coyle KO, Hunt GL Jr, Decker MB, Weingartner TJ (1992) Murre foraging, epibenthic sound scattering, and tidal advection over a shoal near St. George Island, Bering Sea. Mar Ecol Prog Ser 83:1-14

Day RH, Prichard AK, Nigro DA (2003) Ecological specialization and overlap of Brachyramphus murrelets in Prince William Sound, Alaska. Auk 120:680-699

Drent RH (1965) Breeding biology of the pigeon guillemot, Cepphus columba. Ardea 53:99-160

Drew GS, Speckman S, Piatt JF, Burgos JM, Bodkin JL (2008) Survey design considerations for monitoring marine predator populations in Glacier Bay, Alaska: results and post-hoc analyses of surveys conducted in 19992003. USGS administrative report, US Geological Survey, Reston, VA

Duffy DC, Todd FS, Siegfried WR (1987) Submarine foraging behavior of alcids in an artificial environment. Zoo Biol 6:373-378

Etherington LL, Hooge PN, Hooge ER, Hill DF (2007) Oceanography of Glacier Bay, Alaska: implications for biological patterns in a glacial fjord estuary. Estuaries Coasts 30:927-944

Fauchald P, Erikstad KE, Skarsfjord H (2000) Scaledependent predator-prey interactions: the hierarchical spatial distribution of seabirds and prey. Ecology 81: 773-783

Francis RC, Hare SR, Hollowed AB, Wooster WS (1998) Effects of interdecadal climate variability on the oceanic ecosystems of the NE Pacific. Fish Oceanogr 7 : $1-21$ 
Gould PJ, Forsell DJ (1989) Techniques for shipboard surveys of marine birds. Tech Rep 25, US Fish \& Wildlife Service, Washington, DC

Hatch JJ (2002) Arctic tern (Sterna paradisaea). In: Poole A, Gill F (eds) The birds of North America, No. 707. The Birds of North America, Philadelphia, PA

> Heath JP, Gilchrist HG (2010) When foraging becomes unprofitable: energetics of diving in tidal currents by common eiders wintering in the Arctic. Mar Ecol Prog Ser 403:279-290

Hill DF, Ciavola SJ, Etherington L, Klaar MJ (2009) Estimation of freshwater runoff into Glacier Bay, Alaska and incorporation into a tidal circulation model. Estuar Coast Shelf Sci 82:95-107

> Holm KJ, Burger AE (2002) Foraging behavior and resource partitioning by diving birds during winter in areas of strong tidal currents. Waterbirds 25:312-325

Hunt GL, Schneider D (1987) Scale dependent processes in the physical and biological environment of marine birds. In: Croxall J (ed) Seabirds: feeding biology and role in marine ecosystems. Cambridge University Press, Cambridge, p 7-41

Hunt GL Jr, Harrison NM, Cooney RT (1990) The influence of hydrographic structure and prey abundance on foraging of least auklets. Stud Avian Biol 14:7-22

> Hunt GL Jr, Russell RW, Coyle KO, Weingartner T (1998) Comparative foraging ecology of planktivorous auklets in relation to ocean physics and prey availability. Mar Ecol Prog Ser 167:241-259

$>$ Hyrenbach KD, Forney KA, Dayton PK (2000) Marine protected areas and ocean basin management. Aquat Conserv 10:437-458

> Irons DB (1998) Foraging area fidelity of individual seabirds in relation to tidal cycles and flock feeding. Ecology 79: 647-655

Kotzerka J, Hatch SA, Garthe S (2011) Evidence for foraging-site fidelity and individual foraging behavior of pelagic cormorants rearing chicks in the Gulf of Alaska. Condor 113:80-88

> Lewis TL, Esler D, Boyd WS (2008) Foraging behavior of surf scoters and white-winged scoters in relation to clam density: inferring food availability and habitat quality. Auk 125:149-157

Litzow MA, Piatt JF, Abookire AA, Speckman SG, Arimitsu ML, Figurski JD (2004) Spatiotemporal predictability of schooling and non-schooling prey of pigeon guillemots. Condor 106:410-414

> Lovvorn JR, Gillingham MP (1996) Food dispersion and foraging energetics: a mechanistic synthesis for field studies of avian benthivores. Ecology 77:435-451

Lovvorn JR, Liggins GA, Borstad MH, Calisal SM, Mikkelsen J (2001) Hydrodynamic drag of diving birds: effects of body size, body shape and feathers at steady speeds. J Exp Biol 204:1547-1557

Luettich R, Westerink J (1991) A solution for the vertical variation of stress, rather than velocity, in a threedimensional circulation model. Int J Numer Methods Fluids 12:911-928

Maniscalco JM, Ostrand WD, Coyle KO (1998) Selection of fish schools by flocking seabirds in Prince William Sound, Alaska. Colon Waterbirds 21:314-322

> Mileikovsky SA (1971) Types of larval development in marine bottom invertebrates, their distribution and ecological significance: a re-evaluation. Mar Biol 10:
$193-213$

Nur N, Jahncke J, Herzog JP, Howar J and others (2011) Where the wild things are: predicting hotspots of seabird aggregations in the California Current System. Ecol Appl 21:2241-2257

Pawlowicz R (2002) Classical tidal harmonic analysis including error estimates in MATLAB using T_TIDE. Comput Geosci 28:929-937

Pearson TH (1968) The feeding biology of sea-bird species breeding on the Farne Islands, Northumberland. J Anim Ecol 37:521-552

Piatt JF, Wetzel J, Bell K, DeGange AR and others (2006) Predictable hotspots and foraging habitat of the endangered short-tailed albatross (Phoebastria albatrus) in the North Pacific: implications for conservation. Deep-Sea Res II 53:387-398

Pitcher TJ (1973) The three-dimensional structure of schools in the minnow, Phoxinus phoxinus. Anim Behav 21: 673-686

Robards M, Drew G, Piatt J, Anson JM and others (2003) Ecology of selected marine communities in Glacier Bay: zooplankton, forage fish, seabirds and marine mammals. Final Rep for Glacier Bay National Park, US Geological Survey, Anchorage, AK

Robertson I (1974) The food and nesting of double-crested and pelagic cormorants at Mandarte Island, British Columbia, with notes on feeding ecology. Condor 76 : 346-348

> Schneider DC, Piatt JP (1986) Scale-dependent correlation of seabirds with schooling fish in a coastal ecosystem. Mar Ecol Prog Ser 32:237-246

> Schneider DC, Harrison NM, Hunt GL Jr (1987) Variation in the occurrence of marine birds at fronts in the Bering Sea. Estuar Coast Shelf Sci 25:135-141

> Sims DW, Southall EJ, Humphries NE, Hays GC and others (2008) Scaling laws of marine predator search behavior. Nature 451:1098-1102

> Small LF, Menzies DW (1981) Patterns of primary productivity and biomass in the coastal upwelling region. Deep-Sea Res 28:123-149

Smith RL (1968) Upwelling. Oceanogr Mar Biol Annu Rev 6: 11-46

Spargo E, Westerink J, Luettich R, Mark D (2004) ENPAC 2003: a tidal constituent database for the eastern North Pacific Ocean. Report ERDC/CHL TR-04-12 191, United States Army Corps of Engineers, Washington, DC

Spear LB, Ballance LT, Ainley DG (2001) Responses of seabirds to thermal boundaries in the tropical Pacific: the thermocline versus the Equatorial Front. Mar Ecol Prog Ser 219:275-289

Strathmann RR (1985) Feeding and nonfeeding larval development and life-history evolution in marine invertebrates. Annu Rev Ecol Syst 16:339-361

> Suryan RM, Sato F, Balogh GR, Hyrenbach KD, Sievert PR, Ozaki K (2006) Foraging destinations and marine habitat use of short-tailed albatrosses: a multi-scale approach using first-passage time analysis. Deep-Sea Res II 53: 370-386

Thompson SA, Price JJ (2006) Water clarity and diving behavior in wintering common loons. Waterbirds 29: 169-175

US Geological Survey (2012) North Pacific pelagic seabird database. Alaska Science Center, Anchorage, AK

> Vermeer K, Morgan KH, Smith GEJ (1993) Nesting bio- 
logy and predation of pigeon guillemots in the Queen Charlotte Islands, British Columbia. Colon Waterbirds 16:119-129

Weimerskirch H (2007) Are seabirds foraging for unpredictable resources? Deep-Sea Res II 54:211-223

> Wells HW (1957) Abundance of the hard clam Mercenaria mercenaria in relation to environmental factors. Ecology 38:123-128

Wilson RP, Wilson MPT (1988) Foraging behaviour in four

Submitted: July 3, 2012; Accepted: February 6, 2013 sympatric cormorants. J Anim Ecol 57:943-955

Yen PPW, Sydeman WJ, Bograd SJ, Hyrenbach KD (2006) Spring-time distributions of migratory marine birds in the southern California Current: oceanic eddy associations and coastal habitat hotspots over 17 years. DeepSea Res II 53:399-418

Zamon JE (2001) Seal predation on salmon and forage fish schools as a function of tidal currents in the San Juan Islands, Washington, USA. Fish Oceanogr 10:353-366

Proofs received from author(s): March 28, 2013 